\title{
Ruotsalaisen aikuiskasvatuksen ongelmia ja painopisteitä
}

Vuoden 1985 lokakuussa valmistui Sune Ahlénin selvitys 1970-luvun Ruotsin toteutetuista aikuiskasvatusreformeista ja niiden vaikutuksista. Selvityksessä analysoidaan valtiovallan tukeman aikuiskasvatuksen uudistuksia, niiden perusteita sekä volyymien ja kustannusten kehitystä. Selvityksessä on runsaasti samanlaista aineistoa kuin meidän Tilastokeskuksen Aikuiskoulutukseen osallistuminen -tutkimuksessa sekä lisäksi pohdiskelua aikuiskasvatuksen yhteiskunnallisista tehtävistä.

Olen seuraavaan koonnut eräitä keskeisimpiä selvityksen ajatuksia, mutta aikuiskasvatusorganisaatioiden kehittymisen kuvauksen olen jättänyt pois.

\section{Kehittämisen \\ painopistesuuntien muuttuminen}

Ruotsissa on julkisen vallan toimesta kiinnitetty erityistä huomiota kolmen aikuiskasvatuksen osa-alueen kehittämiseen:

- työmarkkinoita palveleva,

- lukiotasoinen ja lukiota edeltävä opetus,

- kansansivistys.

Vuoden 1967 budjettiesityksessä todettiin, että yhteiskunnan tulisi panostaa sellaiseen aikuiskasvatukseen, mikä tehokkaasti tukee Ruotsin talouselämän kehittymistä. Uudelleenkoulutus ja jatkokoulutus katsottiin tärkeimmiksi toimenpiteiksi. Myös aikuisten yksilöllisten opiskelu- ja sivistystarpeiden tyydyttämistä pidettiin tärkeänä. Tämän tulisi kuitenkin tapahtua pääasiassa yleissivistyksen laajentamisena tai nuorisokoulun opetussuunni- telmien mukaisena opiskeluna.

Kunnallisen aikuiskoulutuksen kehittäminen oli etusijalla 1970-luvun alkupuolen budjettiesityksessä. Huomiota kiinnitettiin sukupolvien välisten koulutuskuilujen pienentämiseen. Samanaikaisesti aikuiskasvatus nähtiin merkittävänä yhteiskunnallisena instrumenttina työmarkkinapolitiikassa erityisesti kun tavoitteena oli täystyöllisyyden turvaaminen.

1970-luvun puolivälissä valmistuivat aikuiskasvatuksen kokeilutoimintaa ja aikuisten opintotukea selvittäneiden komiteoiden mietinnöt. Näiden mietintöjen pohjalta tehtyjä uudistusesityksiä perusteltiin sillä, että on välttämätöntä parantaa ennenkaikkea lyhyen koulutuksen saaneiden mahdollisuuksia osallistua aikuiskasvatukseen.

Uudistettaessa opintokerhojen valtionapujärjestelmää vuoden 1980 esitystä perusteltiin sillä, että kansansivistyksen tärkeä tehtävä on tavoittaa koulutuksellisesti ja kulttuurisesti vähäosaiset ryhmät.

Sune Ahlén tiivistää mietinnössään aikuiskasvatuksen yleistavoitteet (övergripande mål) seuraavasti:

Aikuiskasvatus pyrkii:

1. ylittämään koulutuskuiluja ja samalla lisäämään tasa-arvoa ja yhteiskunnallista oikeudenmukaisuutta,

2. lisäämään aikuisten kykyä ymmärtää, kriittisesti tarkastella ja osallistua kulttuuri-, yhteiskunta- ja poliittiseen elämään sekä siten vaikuttaa demokraattiseen yhteiskuntakehitykseen,

3. kouluttamaan aikuisia vaihteleviin työtehtäviin, vaikuttamaan työelämän muutokseen ja täystyöllisyyden saavuttamiseen ja siten edistämään yhteiskunnallista kehitystä, 
4. tyydyttämään aikuisten yksilöllisiä toiveita opiskelu- ja koulutusmahdollisuuksien laajentamisesta sekä tarjoamaan mahdollisuuksia nuoruusiän koulutuksen täydentämiseen.

Mietinnössä määritellään myös aikuiskasvatuksen tärkeimmät tehtävät (övergripande uppgifter) ja ne ovat:

1. koulutetun työvoiman hankkiminen työmarkkinoille,

2. tarjota yksityisille ihmisille mahdollisuus kehittyä harrastuksissaan,

3. vahvistaa ryhmien ja yksityisten ihmisten asemaa työelämässä ja yhteiskunnassa.

Sune Ahlén pitää tarpeellisena, että valtiovalta entistä selvemmin määrittelisi, mitkä aikuiskasvatuksen päämäärät ovat tärkeämpiä kuin toiset. Hän näkee nykyään olevan mahdollista sellaisen aikuiskasvatuksen tukemisen, joka ei noudata niitä jakopoliittisia tavoitteita, joista on päätetty valtiopäivillä. Samanaikaisesti voidaan perustellusti väittää, että kyseinen aikuiskasvatustoiminta noudattaa aikuiskasvatuksen yleistavoitteita.

Sune Ahlénin ehdottaakin, että seuraavat kaksi tavoitetta vahvistettaisiin aikuiskasvatuksen tärkeimmiksi tavoitteiksi, joihin myös tulisi entistä enemmän kohdentaa yhteiskunnan varoja:

1. koulutuskuilujen poistaminen sekä samalla tasa-arvon ja sosiaalisen oikeudenmukaisuuden lisääminen,

2. pyrkimys lisätä aikuisten kykyä ymmärtää ja kriittisesti tarkastella ja osallistua kulttuuri-, yhteiskunta- ja poliittiseen elämään ja siten osallistua demokraattisen yhteiskunnan kehittymiseen.

Priorisoitaviksi ryhmiksi Ahlén määritteli ne aikuiset, joilla on alle kymmenvuotinen koulunkäynti, ja ne jotka eivät osaa lukea, kirjoittaa eivätkä laskea sekä vammaiset, työttömät ja siirtolaiset.

\section{Aikuiskasvatukseen osallistuminen}

Ruotsissa osallistuu aikuiskasvatukseen vuosittain noin $40 \%$ aikuisväestöstä. Suomessa vastaava prosentti lienee nykyään noin 30 . Alla olevaan taulukkoon on koottu Ruotsin 20-64 -vuotiaiden osallistuminen aikuiskasvatuksen eri muotoihin työvuoden 1982/83 aikana.
Taulukko 1. Ruotsalaisten osallistuminen aikuiskasvatukseen 1982/83 sukupuolen mukaan \%.

Henkilöstökoulutus miehet naiset

Opintokerhot $16,5 \quad 11,4$

Ammatilliset kurssit

$11,2 \quad 20,3$

Työllisyyskoulutus

$4,7 \quad 3,8$

$1,0 \quad 0,9$

Korkea-asteen koulutus $\quad 3,2 \quad 4,1$

Kunnallinen aikuis-

kasvatus

$1,8 \quad 3,2$

Kansanopistot

$0,3 \quad 0,6$

Koko aikuiskasvatus yht.

$39,2 \quad 42,3$

Kymmenen vuotta aikaisemmin eli vuonna 1974 aikuiskasvatukseen osallistui miehistä $27.4 \%$ ja naisista $29,1 \%$. Osallistumisen määrä on kasvanut runsaalla 10 prosenttiyksiköllä.

Suomessa tehdyn Tilastokeskuksen osallistumistutkimuksen mukaan työvuonna 1979/80 aikuisista naisista osallistui aikuiskasvatukseen $30 \%$ ja miehistä $23 \%$. Työvuonna 1971/72 naisista osallistui $21 \%$ ja miehistä $20 \%$.

Taulukko 2. Aikuisväestön osallistuminen Suomessa eräisiin keskeisiin opintomuotoihin 1.9.79-31.12.80 (\%)

Kansalais- ja työväenopistot $\%$

Muu vapaa sivistystyö 16

Työnantajan järjestämä koulutus 10

Muu ammatillinen aikuiskoulutus 13 Muu aikuiskoulutus

Vaikka Ruotsin ja Suomen tilastot ovat eri ajanjaksoilta ja eriperusteisia, voitaneen yleisesti todeta osallistumisen olevan Ruotsissa aktiivisempaa kuin Suomessa ja ehkä kokonaisuutena vapaassa sivistystyö on melko lähellä Ruotsin tasoa, mutta muussa aikuiskasvatuksessa jäämme selvästi jälkeen.

\section{Sune Ahlénin yhteenveto}

Ahlén näkee aikuiskasvatuksen tukemisen olevan osa yhteiskunnallista jakopolitiikkaa. Hän toteaa myös, että mikäli aikuiskasvatukseen suunnattuja resursseja ei jatkuvasti lisätä, niin on jaettava nykyään käytössä olevat resurssit uudella tavalla.

Tiivistetysti hän toteaa:

1. Aikuiskasvatukseen osallistuneiden määrät ovat lisääntyneet, 
2. Naiset osallistuvat miehiä aktiivisemmin,

3. Alle 45-vuotiaat opiskelevat vanhempia aktiivisemmin,

4. Paremmassa sosiaalisessa asemassa olevat opiskelevat heikommassa asemassa olevia aktiivisemmin,

5. Suurkaupungeissa opiskellaan aktiivisemmin kuin pienissä kaupungeissa.

Nämä toteamukset noudattavat Suomessa tehtyjä havaintoja.

\section{Ruotsin valtion budjetti}

Varojenhoitovuodelle 1986/87 tehdyssä valtion budjetissa käsitellään aikuiskasvatusta poikkeuksellisen runsaasti otsikon "Vuxenutbildning i utjämningsperspektiv"' alla. Tämä noin kymmensivuinen jakso perustuu pitkälle Sune Ahlénin selvitykseen. Budjetissa nähdään aikuiskasvatuksen tärkeäksi tehtäväksi vaikuttaminen suuremman oikeudenmukaisuuden saavuttamiseen koulutuksen alueella sukupolvien ja yksilöiden välillä. Tästä seuraa selvä kannanotto niiden priorisoimiseksi, jotka ovat saaneet lyhyen koulutuksen ja ovat vielä pitkään työelämässä.

Budjettiesityksessä todetaan muutamia Ahlénin faktoja, eli aikuisopiskeluaktiivisuus on alhaisinta henkilöillä, joilla on lyhin koulunkäynti. Sama toteamus heijastuu myös ikäluokkatarkasteluun: osallistuminen on alhaisinta niissä ikäluokissa, jotka ovat saaneet lyhimmän koulutuksen. Aikuiskasvatukseen osallituminen on korkeinta niiden keskuudes- sa, jotka ovat käyneet lukiokoulun. Suurimmat erot lyhyen ja pitkän koulutuksen saaneiden välillä on nimenomaan henkilöstökoulutuksessa, jossa pitkän peruskoulutuksen saaneiden osuus on erittäin suuri. Henkilöstökoulutuksenhan tarkoituksena ei ole toteuttaa yhteiskunnan koulutuspoliittisia tavoitteita pyrkimällä lisääntyvään tasa-arvoon. Yhteenvetona todetaankin, että aikuiskoulutuksen resurssien pääosa kohdistuu niihin henkilöihin, jotka jo aiemmin ovat saaneet eniten koulutusta.

Budjettiesityksessä ehdotetaan mm. kokeilun aloittamista pyrkimyksenä vapaampi resurssien käyttö. Tämä koskisi erityisesti valtion opintotukikeskusta siten, että sen tulisi väljentää tunti- ja päiväkohtaisen opintotuen säädöksiä ja lisätä hakevaa toimintaa. Samalla ehdotetaan aikuisopintotuen määrän korottamista ja yläikärajan nostamista 45 vuodesta 50:een. Myös ehdotetaan työttömyyskorvauksen säilyttämistä, mikäli henkilö ryhtyy opiskelemaan osapäiväisesti ja erityistapauksissa kokoaikaisesti enintään muutamia viikkoja.

Lisäksi perustellaan lisäresurssien ohjaamista mm. opintoliitoille, jotta ne voisivat aloittaa laajan automattisen tietojenkäsittelyn opetusohjelman. ATK-koulutus saakin budjettiesityksessä runsaasti tilaa.

\section{Lähteet}

Vuxenutbildningen, 1970-talets reformer - en utvärdering. Betänkande från utredningen on vuxenutbildningsreformernas effekter. Ds U 1985:10. 